\title{
Retirement Savings Of Private And Public Sector Employees: A Comparative Study
}

\author{
Swarn Chatterjee, University of Georgia, Athens, USA
}

\begin{abstract}
This study examines the retirement plan participation and savings for United States government employees using the Panel Study of Income Dynamics data set. The findings of this study indicate that plan participation increases with age, income and educational attainment. More Government employees are enrolled in defined benefit plans than non Government employees. Also, those government employees who participate in defined contribution plans hold greater amounts within their plans and make greater contributions into their retirement plans than the non government employees. Minorities and employees with lower income are less likely to participate in the Individual Retirement Accounts, while those with higher educational attainment are more likely to participate.
\end{abstract}

Keywords: Retirement saving, IRA, Plan Participation, Asset Allocation

\section{INTRODUCTION}

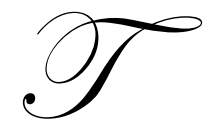

ax deferred retirement savings plans are designed to encourage employee pension participation and to help employees accumulate wealth for their retirement. Currently the most popular pathways for employees to save for retirement, are available through the employment based defined benefits and defined contribution plans; and outside their employer through Individual Retirement Accounts (IRAs). Extant research shows that the majority of participants in these plans comprise of a disproportionately higher number of males, high income earners and full time employees [32].

The U.S. public sector comprises of more than 18 million employees, of whom nearly 12 million are employed with the federal government [18]. U.S. Government employees therefore form a substantial portion of the currently employed workforce. However, the extent of past research directed towards studying U.S. government employees' retirement preparation, plan participation and wealth accumulation is limited. This paper looks at the determinants of retirement plan participation and savings of government employees using the Panel Study of Income Dynamics (PSID). Usage of the more general term government employees throughout this paper implies employees of the U.S. government unless stated otherwise.

\section{LITERATURE REVIEW}

Investment and Wealth

Economic explanations of household savings behavior are based on the hypothesis that rational households will anticipate changes in future income and respond by smoothing consumption in order to maximize their expected lifetime utility. Early research on income and savings of government employees found that public employees on average earned a higher income than employees in the private sector at the same level [31]. Most of the past studies on wealth accumulation of households have shown that a large proportion of households do not save adequately for retirement; when assuming that they want to maintain their pre-retirement level of consumption [4]. Investment assets within household portfolios were greatest for those with higher income, higher educational attainment, and for those who were white. Also, those who were older in age, had higher marginal tax rates and had accumulated greater human capital, were more likely to invest in financial assets. Guiso, Haliassos, and Jappelli [10] found that in the United States, proportion of investors with direct or indirect stockholdings varied from $4.4 \%$ in the lowest quartile of wealth to $86.7 \%$ in the highest quartile of wealth. 


\section{Tax Advantaged Saving Funds}

Munnell and Connolly[21]found that public sector employees had superior tax savings retirement options than did private sector employees. Quinn [30] found that a much larger number of government employees participated in pension plans, as opposed to the private sector employees. In a more recent study, the researchers found that $65 \%$ of eligible workers participated in $401(\mathrm{k})$ plans. Another finding of this paper was that fewer number of lower income workers participated in the 401(k) plan to save for their retirement [3]. Bassett et al [3] also found in their paper that the number of defined contribution plans offered to the employees increased steadily across time and most of these plans substituted the previously existing defined benefit plans. The reason for the increased popularity of the defined contribution plan was due to the greater cost savings these plans brought to the employers, when compared with the earlier defined benefit plans [13] [23]. Engelhardt [8] found in his study, using the health and retirement survey (HRS) that nearly $33 \%$ of all pension plans and $45 \%$ of all active pension participants were in 401 (k) plans. Poeterba, Venti and Wise [26] also predicted the growth of 401(k) participation among younger employees in the future.

The Bassett et. al [3] study also found that higher employer match rates, higher income, age, job tenure, homeownership and education increased the likelihood of employee participation in 401(k) plans. Yuh \& DeVaney [36] found that couples who had higher income and held a lower level of non financial assets, made larger contributions to their 401 (k) plans. Munnell, Sunden and Taylor [22] found from their study, using the Survey of Consumer Finances that the probability of 401(k) participation increased with age, job tenure and income. Net worth also had a small but significant effect on participation. Engelhardt [7] found that retirement savings plans such as the 401 (k) increased savings among lower and middle income households. An earlier study by Venti and Wise [33] found that tax advantaged savings accounts increased the savings of lower to middle income participants. Other research on 401 (k) plans found that participation increased with age, income and with men as compared to women. Participation was lower for African American households as compared to the whites [11].

\section{METHODS}

\section{Data and Sample}

For empirical analysis in this study, the data from the Panel Study of Income Dynamics (PSID) is used. The Panel Study of Income Dynamics (PSID) is an ongoing nationally representative longitudinal study of approximately 8,000 families living in the United States. The survey focuses on household socioeconomic, demographic and behavioral characteristics. The attrition rate from 1968 to 1969 was $11 \%$, but since then it remained at approximately 2 to $3 \%$ annually [6]. The most recent survey, which is used for this analysis, was conducted in 2005. For the purpose of this study employed heads of households below age 65 are considered, bringing the overall sample to 4,585 .

\section{Variables Used in the Analysis}

Employee participation in tax sheltered accounts is the dependent variable for the first part of this study. The Panel Study of Income Dynamics asks the retirement plan participation questions to employed respondents who are 64 or younger. Using variables from 2005 data of the PSID, three separate analyses are performed to investigate employee participation in IRAs, defined benefit plans and defined contribution plans. All three of these variables are coded in this study as ' 1 ' for participation and as ' 0 ' if otherwise. The next part of this study examines two continuous dependent variables, the amount of defined contribution holding and the amount of voluntary contribution made into the defined contribution plans.

The independent variable of interest in this study is employment in a government job. This is coded as ' 1 ' for government employee and ' 0 ' if otherwise. Other control variables comprise of demographic, financial and socioeconomic characteristics. Age is included because it is a significant predictor of financial asset holdings, as well as a predictor of retirement plan participation [12]. For this study age has been split into quartiles. The lowest quartile and the reference group for this study are respondents less than or equal to the age of 30 . The other three quartiles are age groups between 31-40; 41-50 and 51-64. Prior research has shown that whites are more likely than 
minorities to hold high-risk and high-return assets [15]. Hence in order to control for this demographic difference, race is included as a control variable. Education is included in the model since past research has shown that educational attainment positively correlates with investment in $401(\mathrm{k})$ plans [34][24]. Education, marital status, and gender are also controlled because of their association with wealth and retirement plan participation in prior literature [32][36][37]. Numbers of children are included as well. Keister [16] found that having greater number of children associated negatively with ownership of investment assets. Past research found that income had a positive effect on amount invested in defined contribution plans [29]. Therefore, $\log$ value of the total family income is also included as a control variable. Finally, voluntary contribution to retirement plans and number of years of enrollment in retirement plans is included as control variables due to their association with pension plan savings [25].

\section{Analysis}

A descriptive statistical analysis is initially performed for examining the demographic composition, educational attainment, income, and investment characteristics of government and private sector employees. The first part of this study examines the determinants of retirement plan participation and whether government employees differ significantly from others in their preference for tax advantaged retirement accounts, after controlling for income, educational attainment, demographic differences as well as socioeconomic factors. The three dependent variables for participation in defined benefit plan, defined contribution plan and individual retirement account, are coded as binary categorical variables. Probit estimation technique is used for calculating the coefficients of the hypothesized variables. These estimates are then applied to calculate the predicted probabilities or the marginal effects for the independent variables using the STATA software. The second part of the study, investigates factors that determine the amount of saving in defined contribution plans and the amount of voluntary contributions that employees make into their retirement plans. To analyze the factors affecting savings in defined contribution plan as well as the amount of voluntary contribution made into these plans, tobit analysis is performed in order to control for the non participation bias which may result from a number of respondents reporting zero value for their savings or voluntary contribution into the retirement plans [35].

\section{RESULTS}

\section{Descriptive Statistics}

Table 1 shows the demographic and socioeconomic composition as well as investment participation rates of government and non government employees. The total sample size is 4,585, of whom approximately $13 \%$ work for the government. The median wealth for government employees $(\$ 53,000)$ in 2005 is higher than that of others $(\$ 43,450)$. However, the average wealth of government employees is less than the average wealth of the general population. Also, the median family income for government employees $(\$ 57,292)$ is higher than that of other respondents $(\$ 44,690)$. Government employees have higher participation rates in homeownership and in financial asset ownership such as stocks, bonds and mutual funds. Although, investment participation among government employees appear to be higher, the descriptive analyses of the data also reveals that government employees also carry a higher debt load on average. The average mortgage debt for government employees is $\$ 480,770$ as compared to $\$ 396,333$ for the population. Also, government employees report on average a higher car loan balance than others. The average credit card debt for government employees is $\$ 9,229$, as compared to $\$ 7,960$ for the entire sample. Government employees seem to have lower participation rates for defined contribution plans, across all age groups. Further descriptive analysis of the data showed that the distribution of IRA participation appears to increase monotonically with age, while the participation of government employees in IRAs is lower across all age groups.

\section{Determinants of participation in tax advantaged retirement funds}

The results from Table 2 reveal that government employees are more likely to participate in defined benefit plans. The estimates from the models indicate that government employees are approximately $36 \%$ more likely to participate in a defined benefit plan. Conversely the government employees are $4.32 \%$ less likely to participate in a defined contribution plan when compared with others in the private sector. Also, the probit estimates from IRA participation show that government employees are less likely than the reference group of private sector employees, to have an IRA. 
Table 1: Descriptive Statistics

\begin{tabular}{|c|c|c|c|}
\hline $\mathrm{N}=4585$ & All & Gov Employee & Non Gov. employee \\
\hline Overall & $100 \%$ & $13 \%$ & $87 \%$ \\
\hline Age & 45 & 43 & 45 \\
\hline$\%$ Male & 70 & 68 & 70 \\
\hline$\%$ Married & 51 & 55 & 53 \\
\hline Children & 0.85 & 0.89 & 0.84 \\
\hline \multicolumn{4}{|l|}{ Race } \\
\hline$\%$ White & 60 & 55 & 61 \\
\hline$\%$ Black & 31 & 38 & 29 \\
\hline$\%$ Hispanic & 5 & 4 & 5 \\
\hline$\%$ Asian & 3 & 2 & 4 \\
\hline \%Others & 1 & 1 & 1 \\
\hline \multicolumn{4}{|l|}{ Education } \\
\hline \%Less than High School & 27 & 12 & 27 \\
\hline$\%$ High School Grad & 30 & 27 & 30 \\
\hline$\%$ Some College & 22 & 25 & 22 \\
\hline$\%$ College Graduate & 13 & 22 & 13 \\
\hline \%Graduate Education & 8 & 14 & 8 \\
\hline Mean Family Income (Annual) & $\$ 62,176$ & $\$ 67,109$ & $\$ 61,416$ \\
\hline Median Family Income (Annual) & $\$ 44,690$ & $\$ 57,292$ & $\$ 42,038$ \\
\hline Mean Wealth04 & $\$ 229,130$ & $\$ 178,959$ & $\$ 236,857$ \\
\hline Median Wealth04 & $\$ 43,450$ & $\$ 53,000$ & $\$ 41,100$ \\
\hline \multicolumn{4}{|l|}{ Investment Participation } \\
\hline \%Homeowner & 59 & 66 & 58 \\
\hline \%Have Checking/ Savings Accounts & 74 & 82 & 74 \\
\hline \%Have Other Savings (Bonds, ins) & 16 & 18 & 16 \\
\hline \%Have Stocks/ Mutual Funds & 18 & 19 & 18 \\
\hline \multicolumn{4}{|l|}{ Debt } \\
\hline Mortgage Debt & $\$ 396,333$ & $\$ 480,770$ & $\$ 383,328$ \\
\hline Car Loan & $\$ 30,120$ & $\$ 37,103$ & $\$ 29,044$ \\
\hline Debt other than Mortgage or Car & $\$ 7960$ & $\$ 9229$ & $\$ 7765$ \\
\hline \% Have Credit Card Debt & 53 & 62 & 52 \\
\hline
\end{tabular}

Table 2: Probit Estimation Of Participation In Retirement Funds

\begin{tabular}{|c|c|c|c|c|c|c|c|c|c|}
\hline \multirow[t]{2}{*}{ Variables } & \multicolumn{3}{|c|}{$\begin{array}{c}\text { Participation in Defined } \\
\text { Contribution Plans }\end{array}$} & \multicolumn{3}{|c|}{$\begin{array}{c}\text { Participation in Defined Benefit } \\
\text { Plans }\end{array}$} & \multicolumn{3}{|c|}{$\begin{array}{c}\text { Participation in Individual } \\
\text { Retirement Accounts }\end{array}$} \\
\hline & Coefficient & $\begin{array}{l}\text { Marginal } \\
\text { Effects }\end{array}$ & & Coefficient & $\begin{array}{c}\text { Marginal } \\
\text { Effects } \\
\end{array}$ & & Coefficient & $\begin{array}{l}\text { Marginal } \\
\text { Effects }\end{array}$ & \\
\hline Gov Employee & -0.32 & $-4.32 \%$ & $* * *$ & 1.14 & $35.96 \%$ & $* * *$ & -0.09 & $-3.31 \%$ & $*$ \\
\hline Age3140 & 0.14 & $5.05 \%$ & & 0.15 & $5.13 \%$ & & 0.13 & $4.29 \%$ & \\
\hline Age 5164 & 0.23 & $8.96 \%$ & $* * *$ & 0.27 & $9.12 \%$ & $* * *$ & 0.48 & $15.61 \%$ & $* * *$ \\
\hline Black & -0.02 & $-0.35 \%$ & & 0.05 & $1.06 \%$ & & -0.64 & $-21.27 \%$ & $* * *$ \\
\hline Hispanic & 0.02 & $0.35 \%$ & & -0.4 & $-7.49 \%$ & $* * *$ & -0.48 & $-15.07 \%$ & $* * *$ \\
\hline Others & -0.05 & $-0.71 \%$ & & -0.14 & $-2.96 \%$ & & 0.09 & $3.19 \%$ & \\
\hline Male & -0.08 & $-1.23 \%$ & & -0.4 & $-10.35 \%$ & $* * *$ & -0.08 & $-1.46 \%$ & \\
\hline Children & -0.04 & $-0.69 \%$ & $*$ & -0.06 & $-1.34 \%$ & & -0.09 & $-3.31 \%$ & $* * *$ \\
\hline Married & -0.03 & $-0.48 \%$ & & 0.13 & $2.88 \%$ & $* *$ & 0.27 & $9.48 \%$ & $* * *$ \\
\hline Some College & 0.19 & $3.16 \%$ & $* *$ & 0.37 & $9.33 \%$ & $* * *$ & 0.27 & $10.08 \%$ & $* * *$ \\
\hline College & 0.24 & $4.32 \%$ & $* * *$ & 0.39 & $10.28 \%$ & $* * *$ & 0.61 & $23.27 \%$ & $* * *$ \\
\hline Grad School & 0.25 & $4.54 \%$ & $* *$ & 0.25 & $6.24 \%$ & $* *$ & 0.8 & $30.73 \%$ & $* * *$ \\
\hline Log Income & 0.27 & $4.24 \%$ & $* * *$ & 0.41 & $9.51 \%$ & $* * *$ & 0.48 & $17.35 \%$ & $* * *$ \\
\hline Pseudo $\mathrm{R}^{2}$ & 23.50 & & & 27.10 & & & 27.96 & & \\
\hline LR Chi2 & 410.48 & & $* * *$ & 501.28 & & $* * *$ & 489.33 & & $* * *$ \\
\hline
\end{tabular}


Table 3: Tobit Model For Amount In Dc Plan

\begin{tabular}{lcrc}
\hline & & Full Model & St. Error \\
\cline { 2 - 4 } Variables & Coefficient & 10607 & $*$ \\
\hline Gov Employee & 20150.3 & 18135.9 & $* * *$ \\
Vol. Contribution & 76413.8 & 14870.2 & 14951.7 \\
Age3140 & 8999.6 & 15559.2 & $* *$ \\
Age 4150 & 19157.2 & 11967 & \\
Age5164 & 34616.1 & 9366.92 & \\
Married & -11784 & 13578.4 & \\
White & 3331.89 & 4007.35 & $* * *$ \\
Male & -22166 & 12862.5 & $* * *$ \\
Children & -6125.8 & 13260.4 & $* * *$ \\
High School & 38035.1 & 14614.2 & $* *$ \\
Some College & 40863.7 & 16424.4 & $* * *$ \\
College & 35744.4 & 6656.45 & $* * *$ \\
Grad School & 54837.7 & 10774.9 & $* * *$ \\
Log Family Income & 73275.7 & 7121.09 & $* * *$ \\
Homeowner & 32533.1 & & \\
Intercept & -112284.8 & & \\
Log Likelihood & -8034.81 & 25.47 & $* * *$
\end{tabular}

Table 4: Tobit For Amount Of Voluntary Contribution

\begin{tabular}{|c|c|c|c|}
\hline \multirow[b]{2}{*}{ Variables } & \multicolumn{3}{|c|}{ Full Model } \\
\hline & Coefficient & St. Error & \\
\hline Gov Employee & 1891.88 & 596.83 & $* * *$ \\
\hline Age 3140 & 4735.14 & 1217.40 & $* * *$ \\
\hline Age 4150 & 5278.17 & 984.66 & $* * *$ \\
\hline Age5164 & 5176.09 & 1040.20 & $* * *$ \\
\hline Married & -641.75 & 746.70 & \\
\hline White & 152.284 & 556.20 & \\
\hline Male & -2170.1 & 814.94 & $* * *$ \\
\hline Children & 111.351 & 234.37 & \\
\hline High School & 782.862 & 765.52 & \\
\hline Some College & 778.669 & 797.14 & \\
\hline College & -128.47 & 904.92 & \\
\hline Grad School & 2414.25 & 956.85 & $* *$ \\
\hline Log Family Income & 3193.13 & 403.22 & $* * *$ \\
\hline Homeowner & 640.618 & 639.29 & \\
\hline Intercept & -52511 & 4509.32 & $* * *$ \\
\hline Log Likelihood & -3334.5 & & \\
\hline Pseudo R square & 21.72 & & \\
\hline Wald Chi Square & 556.61 & & $* * *$ \\
\hline
\end{tabular}

Among demographic variables, when compared with the reference group of respondents who are 30 years or younger, those who are in the age groups of 41-50 and 51-64 years were more likely to participate in defined contribution plans; in defined benefit plans; and have Individual Retirement Accounts. This finding is also consistent with past studies [3][2]. Blacks are significantly less likely to have an IRA, while Hispanics are less likely to have a defined benefit plan or an IRA. The results also indicate that men are less likely than women to have defined benefits plan. Also, number of children is a negative predictor for participation in a defined contribution plans or for having an Individual Retirement Account. Other studies in the past have also found that number of children is negatively associated with wealth creation [14]. Married households are significantly more likely to have 
a defined benefit plan or an IRA. Earlier studies have also found that being married is a positive predictor of wealth accumulation and investment participation [32][37]. Educational attainment is a significant predictor of participation in defined benefits plans, defined contribution plans as well as Individual Retirement Accounts. This finding is also in agreement with the findings from past research [3]. In this study attending college, completion of college and graduate education variables are significant predictors of participation for all three retirement funds-defined benefit, defined contribution as well as IRA. Those who have at least a high school diploma are also more likely to have a defined benefit plan or a defined contribution plan, as opposed to those who have not completed their high school. Among socioeconomic variables, income is positively associated with participation in defined benefit plans; it is also a positive predictor of defined contribution plan participation and increases the likelihood of having an IRA.

\section{Determinants of amounts saved within Defined Contribution plans}

Results from a tobit analysis on the amount of defined contribution funds held by couples are presented in table 3. Government employees are likely to save more than others in their defined contribution plans. Also, making voluntary contribution into the retirement plans is a positive predictor holding larger amounts within these plans. Log of family income is also significant and is positively associated with having higher amount of savings within the retirement plans. Age groups between 51 and 64 years are significantly more likely to have larger amounts in their defined contribution plans, when compared to those who are younger than 31 . When compared with respondents with educational attainment of lower than high school education, those who have educational attainment of high school or higher are likely to have greater savings within their DC plans. Finally, the homeowners are also more likely to have greater wealth saved within their defined contribution plans.

\section{Determinants of the amount of voluntary retirement contributions}

Table 4 shows the results for determinants of the amount of voluntary contributions made into the retirement plans. Government employees are significantly more likely than others to make voluntary contributions into their retirement accounts. Among other control variables, log of family income is positively associated with the amount of voluntary contribution made. All age groups 31 or older when compared with the control group of those who are below the age of 31 are positively associated with the amount of voluntary contribution made. Men made less voluntary contributions than women in the study. Also, those who have greater than college level education, contributed more voluntarily into their retirement plans in 2005.

\section{DISCUSSION}

This study investigates the factors associated with participation as well as wealth holding within retirement plans, using the 2005 Panel Study of Income Dynamics. Results from the probit analyses of the likelihood of saving in retirement plans reveal that government employees are more likely than others to participate in defined benefit plans and less likely to hold defined contribution plans when compared with those who are working in the private sector. This is not surprising since the number of defined benefits plans offered in private sector has reduced substantially over the years and these have since been replaced by the defined contribution plans. Also, the significance of income for participation in retirement plans as well as for participation in the individual retirement accounts, suggests that households who have sufficient capital for present consumption are more likely to invest their surplus income into the tax deferred retirement plans and accounts. The increasing tax advantage for retirement contributions of those in higher income brackets most likely also contributed to retirement plan participation for these individuals. The significance of educational attainment in plan participation underscores the importance of human capital in retirement planning and retirement preparedness of households. The negative relationship between black and Hispanic households and IRA participation may imply a lack of retirement preparedness and perhaps a lack of investment experience in the risky assets among minorities. It is also possible that the minority households rely more heavily on other forms of public assistance such as social security. The positive association of older age groups with retirement plan participation and savings is consistent with findings of past studies [29].

In the second part of our analysis, the determinants of the amount held within defined contribution plans and the determinants of making voluntary contributions into the retirement plans are examined. Analysis of the 
second part reveals that even though government employees are less likely than others to have defined contribution plans, those government employees that do have them, are likely to hold more wealth in these accounts than others and make more voluntary contribution into their plans than their control group. Income and educational attainment are also positively associated with greater amounts being held in defined contribution plans as well as for making greater voluntary contributions. This finding again suggests that those who are able to sustain regular household expenses and have greater human capital are likely to save more for their retirement. The significant relationship of households closer to retirement with saving and voluntary contribution can possibly be explained through the life cycle hypothesis; in which households gradually increase their savings across their life time [20]. The likelihood of contribution is higher for age groups in their highest income earning years (51-64).

\section{CONCLUSION}

The findings of this paper are relevant for employers, retirement plan providers, financial planners, policy makers and educators. The findings reveal that although the government employees lag behind in DC plan participation, the participating government employees hold greater wealth in these plans. Also, in order to better prepare employees for retirement, they must be encouraged to have greater risky asset ownership and IRA participation. Those with lower educational attainment, the minorities and lower wage earners, need special consideration and greater community based efforts must be directed to prepare them for retirement. For future research, this study can be broadened from its present cross sectional form to a longitudinal one. Future studies also need to focus on studying the substitution effects and opportunity costs of investing in different asset classes both within and outside the tax sheltered plans.

\section{AUTHOR INFORMATION}

Swarn Chatterjee is an Assistant Professor in the Department of Housing and Consumer Economics at the University of Georgia. He has a Ph.D. and an MBA from Texas Tech University. His research interests include individual investment behavior and consumer decision making under uncertainty. Dr. Chatterjee has published in leading journals such as the Journal of Real Estate Research, Applied Economics Letters, Economics Bulletin, Financial Services Review and Financial Decisions. He can be contacted at swarn@uga.edu.

\section{REFERENCES}

1. Ameriks, J. and Zeldes, S. P., "How do household portfolio shares vary with age", Unpublished manuscript, Columbia University, (2000)

2. $\quad$ Andrews, E., "The Growth and Distribution of 401 (k) Plans", Trends in Pensions, (1992)

3. Bassett, W. F. and Michael, J., "How Workers Use 401 (k) Plans: The Participation, Contribution, and Withdrawal", National Tax Journal, Vol. 51, No. 2 (1998)

4. Bernheim, B., "Financial Illiteracy, Education, and Retirement Saving", Living with Defined Contribution Pensions, (1998)

5. Campbell, J. Y. and Viceira, L. M., Strategic Asset Allocation: Portfolio Choice for Long-Term Investors, 2002, Oxford University Press (Oxford, England)

6. Duncan, G., Daly, M., et al., "Optimal Indicators of Socioeconomic Status for Health Research", American Journal of Public Health, Vol. 92, No. 7 (2002)

7. Engelhardt, G., "Reasons for job change and the disposition of pre-retirement lump-sum pension distributions", Economics Letters, Vol. 81, No. 3 (2003)

8. $\quad$ Engelhardt, G., "Pre-Retirement Lump-Sum Pension Distributions and Retirement Income Security: Evidence from the Health and Retirement Study", National Tax Journal, Vol. 55, No. 4 (2002)

9. Guiso, L., Haliassos, M., et al., "Household Portfolios: An International Comparison", Household Portfolios, MIT Press, (Cambridge, Mass.), (2002)

10. Gutter, M., Hayhoe, C., et al., "Examining Participation Behavior in Defined Contribution Plans Using the Transtheoretical Model of Behavior Change", Financial Counseling and Planning, Vol. 18, No. 1 (2007)

11. Haurin, D. R., Wachter, S. M., et al., "Wealth Accumulation and Housing Choices of Young Households: An Exploratory Investigation", Journal of Housing Research, Vol. 7, No. 1 (1996) 
12. Ippolito, R. and Thompson, J., "The Survival Rate of Defined-Benefit Plans, 1987-1995", Journal of Economy and Society, Vol. 39, No. 2 (2000)

13. Keister, L., "Sharing the wealth: the effects of siblings on adults' wealth ownership", Demography, Vol. 4, (2003)

14. Keister, L. A., "Race and Wealth Inequality: The Impact of Racial Differences in Asset Ownership on the Distribution of Household Wealth", Social Science Research, Vol. 29, No. 4 (2000)

15. Keister, L. A., "Sharing the Wealth: The Effect of Siblings on Adults' Wealth Ownership", Demography, Vol. 40, No. 3 (2003)

16. Klos, A. and Weber, M., "Portfolio choice in the presence of nontradeable income: An experimental analysis", German Economic Review, Vol. 7, No. 4 (2006)

17. Light, P. C., The True Size of Government, 1999, Brookings Institution Press (Washington, D.C.)

18. Mitchell, O. and Moore, J., "Can Americans Afford to Retire? New Evidence on Retirement Saving Adequacy", Journal of Risk and Insurance, Vol. 65, (1998)

19. Modigliani, F. and Ando, A., "Tests of the life cycle hypothesis of savings", Bulletin of the Oxford Institute of Statistics, Vol. 19, No. 2 (1957)

20. Munnell, A. and Connolly, A., "Comparability of Public and Private Compensation: The Issue of Fringe Benefits", New England Economic Review, Vol. No. (1979)

21. Munnell, A., Sundén, A., et al., "What Determines 401 (k) Participation and Contributions?", Social Security Bulletin, Vol. 64, No. 3 (2001)

22. Papke, L. E., "Are 401 (k) Plans Replacing Other Employer-Provided Pensions? Evidence from Panel Data", NBER Working Paper, (1996)

23. Peress, J., "Wealth, Information Acquisition, and Portfolio Choice", The Review of Financial Studies, Vol. 17, No. 3 (2004)

24. Poterba, J., Venti, S., et al., "Do 401 (k) contributions crowd out other personal saving?", Journal of Public Economics, Vol. 58, No. 1 (1995)

25. Poterba, J., Venti, S., et al., "401 (k) Plans and Future Patterns of Retirement Saving", American Economic Review, Vol. 88, (1998)

26. Poterba, J. M. and Samwick, A., "Household Portfolio Allocation Over the Life Cycle", NBER Working Paper No. W6185., (1997)

27. Poterba, J. M. and Samwick, A., "Taxation and Household Portfolio Composition: US Evidence from the 1980s and 1990s", NBER Working Paper. (1999)

28. Poterba, J. M., Venti, S. F., et al., "How Retirement Saving Programs Increase Saving", Journal of Economic Perspectives, Vol. 10 (1996)

29. Quinn, J., "Wage differentials among older workers in the public and private sectors", Journal of Human Resources, Vol. 14, No. 1 (1979)

30. Quinn, J., "Pension Wealth of Government and Private Sector Workers", American Economic Review, Vol. 72, No. 2 (1982)

31. Springstead, G. R. and Wilson, T. M., "Participation in Voluntary Individual Savings Accounts: An Analysis of IRAs, 401(k)s, and the TSP", Social Security Bulletin, Vol. 63, No. 1 (2000)

32. Venti, S. and Wise, D., Issues in the Economics of Aging, 1990, National Bureau of Economic Research (Chicago, IL) pp. 13-29

33. Wolff, E. N., "Recent Trends in the Size Distribution of Household Wealth", The Journal of Economic Perspectives, Vol. 12, No. 3 (1998)

34. Wooldridge, J., Introductory Econometrics: A Modern Approach, $2^{\text {nd }}$ e.d, 2003, South-Western, (Stamford, C.T.)

35. Yuh, Y. and DeVaney, S., "Determinants of couples' defined contribution retirement funds", Financial Counseling and Planning, Vol. 7, (1996)

36. Zagorsky, J., "Do you have to be smart to be rich? The impact of IQ on wealth, income and financial distress", Intelligence, Vol. 35, No. 5 (2007)

37. Zhong, L. X. and Xiao, J. J., "Determinants of family bond and stock holdings", Financial Counseling and Planning, Vol. 6, (1995) 